Jurnal Nisbah Vol. 4 No. 1 T ahun $2018 \mid 64$

\title{
DISCLOSURE OF ISR AND GRI INDEX ON SHARIA BANKING IN INDONESIA
}

\author{
KETERBUKAAN ISR DAN GRI INDEX PADA BANK SYARIAH DI INDONESIA
}

\begin{abstract}
Andi Zulfikar Darussalamª
1aFaculty of Economics and Business Universitas Internasional Semen Indonesia, Kompleks PT. Semen Indonesia (Persero) Tbk., Jl. Veteran, Sidokumpul, Gresik, Kb. Dalem, Sidokumpul, Kec. Gresik, Kabupaten Gresik, Jawa Timur 61122, E-mail: andi.darussalam@uisi.ac.id
\end{abstract}

\begin{abstract}
The purpose of this paper is to examine the effect of sharia governance by sharia supervisory boards and audit committees on the disclosure of the Islamic Social Reporting Index (ISRI) and Global Reporting Index (GRI). Sharia banks are currently using the Social Reporting Index (SRI) and the Global Reporting Index (GRI). These have been researched by previous research that found weaknesses sharia governance in sharia banking sector in Indonesia. This research uses quantitative method by using purposive sampling technique. Analytical techniques used are multiple regression techniques (multiple regression) and Independent Samples T-test. The results of this study found that the role of directors of sharia banks affects the disclosure with the index of ISR, while the sharia supervisory board is influential in disclosure using the GRI index. The result of independent samples T-test found that the disclosure with ISR index is higher compared to GRI index. The implications of this research are the weakness of sharia governance in sharia banking in Indonesia during the study period 2013-2016, so that this can be an input for sharia banking, Bank Indonesia, and sharia supervisory board. This research develops previous research by examining the effect of sharia governance function in optimizing disclosure with ISR and GRI index.
\end{abstract}

Keywords: sharia governance, sharia bank directors, sharia supervisory board, audit committee, Islamic Social Reporting Index, Global Reporting Index.

\begin{abstract}
ABSTRAK
Tujuan dari makalah ini adalah untuk menguji pengaruh tata kelola syariah oleh dewan pengawas syariah dan komite audit pada pengungkapan Indeks Pelaporan Sosial Islam (ISRI) dan Indeks Pelaporan Global (GRI). Bank-bank syariah saat ini menggunakan Indeks Pelaporan Sosial (SRI) dan Indeks Pelaporan Global (GRI). Ini telah diteliti oleh penelitian sebelumnya yang menemukan kelemahan tata kelola syariah di sektor perbankan syariah di Indonesia. Penelitian ini menggunakan metode kuantitatif dengan menggunakan teknik purposive sampling. Teknik analisis yang digunakan adalah teknik regresi berganda (regresi berganda) dan Independent Samples T-test. Hasil penelitian ini menemukan bahwa peran direksi bank syariah mempengaruhi pengungkapan dengan indeks ISR, sedangkan dewan pengawas syariah berpengaruh dalam pengungkapan menggunakan indeks GRI. Hasil uji independen T-test menemukan bahwa pengungkapan dengan indeks ISR lebih tinggi dibandingkan indeks GRI. Implikasi dari penelitian ini adalah lemahnya tata kelola syariah pada perbankan syariah di Indonesia selama periode penelitian 2013-2016, sehingga ini dapat menjadi
\end{abstract}


masukan bagi perbankan syariah, Bank Indonesia, dan dewan pengawas syariah. Penelitian ini mengembangkan penelitian sebelumnya dengan menguji pengaruh fungsi tata kelola syariah dalam mengoptimalkan pengungkapan dengan indeks ISR dan GRI.

Kata kunci: tata kelola syariah, direktur bank syariah, dewan pengawas syariah, komite audit, Indeks Pelaporan Sosial Islam, Global Reporting Index.

Andi Sulfikar Darussalam. 2018. Disclosure Of ISR And GRI Index On Sharia Banking In Indonesia. Jurnal Nisbah 4 (1): 64-71

\section{INTRODUCTION}

Nowadays measurement of responsibilities in many sharia banking still refers to the Global Reporting Initiative Index (GRI index). Whereas the need for CSR disclosure in sharia banking, is currently rife about the Islamic Social Reporting Index (ISR index). The ISR index is an implementation benchmark performance of sharia banking that compiles standard items set by AAOIFI (Accounting and Auditing Organization for Islamic Financial Institutions). The ISR index is believed to be an early stage in terms of social disclosure standards that are compatible with Islam. Currently, research on ISR index in sharia banking industry is still rare in Indonesia, therefore we are interested to investigate further for the development of sharia economy in Indonesia.

The management of sharia banks in Indonesia refers to the principles of Good Governance of Sharia Business (GGBS) set by Bank Indonesia (BI). This is expected to encourage the establishment of a good sharia bank financially and in compliance with sharia principles in all its operational lines. According to Siddiqi (1980), sharia banks must have a much greater purpose than just to achieve maximum profit and also must strive to realize the Maqashid Sharia. Standardized governance guidelines that are in line with Sharia principles will achieve the Maqashid Sharia.

The organizational structure studied in this study consists of directors, sharia supervisory board (DPS) and audit committee, which is also sharia governance in sharia banking the board of directors in sharia banking was chosen in this study because the board of directors as corporate organ duty and responsible collegial in managing the company.

According to KNKG (2006), the audit committee is responsible for assisting the board of commissioners to ensure that the financial statements are fairly presented in accordance with generally accepted accounting principles, the internal controls of the company are well implemented, the internal and external audits are carried out in accordance with applicable auditing standards, and follow-up findings of audit results carried out by management.

Disclosure of ISR index and GRI index in sharia banking industry in Indonesia, in accordance with the business characteristics of Indonesian society, is expected to be comparable with the standards set at the international level. However, if the ISR index already includes the concept of disclosure in the GRI index, it is expected that sharia banks can use the ISR index in order to become a benchmark for the regulator for the development of the sharia banking 
industry in the future and in preparing the operational business framework, as well as other industry players in the activities and associated with sharia banking. Based on the above description, the problems in this research are:

1) Does sharia governance (board of directors, sharia supervisory board and audit committee) affect the ISR index?

2) Does sharia governance (board of directors, sharia supervisory board and audit committee) affect GRI index?

3) Is there a comparison between reporting disclosure using ISR and GRI index?

\section{THEORETICAL BASIS}

Agency theory is a concept that describes agent and principal in a contractual model between two or more parties, in which one party is called an agent and the other is called principal. Agent is also called the manager, who has the authority and responsibility provided by the principal. It can be said that the principal provides a mandate to the agent to perform certain tasks in accordance with the contract of work that has been agreed. Stakeholder theory is used in this research because shareholders or stakeholders are interested parties of companies who want financial and non-financial information of a company. According to Guthrie, Petty, and Ricceri (2006), financial statements and annual reports are the most efficient way for organizations to communicate with shareholders groups in controlling certain strategic aspects of the organization

The GRI Index has developed a standardized reporting approach to drive demand for sustainability information that will benefit organizational reporting and to those using similar reporting information. Disclosure of sustainability reports comprises assessment indicators in the Global Reporting Initiatives using Anonymous guidelines (2006a), which comprise economic, environmental, labor and employment indicators, human rights, community and product responsibilities

Social Reporting is an extension of the financial reporting system that reflects the new and broader estimates of society with respect to the role of the business community in the economy (Hannifa, 2002). Gray et al. (1987) in Maali (2006) states that identifying the responsibilities of an organization is a problem because responsibility continues to change over time. Islam has explained quite clearly about the rights and obligations for individuals as well as for organizations based on Al-Quran and Hadith. This is because Islam is a religion that completely regulates all aspects of human life on earth. Siwar and Hossain (2009) stated that the basic foundations of Islam are belief, faith, worship, morality and ethics. There is a need for a specific framework for reporting social responsibility in accordance with Islamic principles. This framework is known as Islamic Social Reporting (ISR) Haniffa (2002).

The board of directors is a corporate governance mechanism that plays an important role in increasing the disclosure of ISR index and GRI index. The Board of directors has a role not only limited to routine activities, but also authorized and obliged to take the initiative to make plans and estimates of the company's future development in order to realize the intent and purpose of the company, therefore it takes a number of directors who are adjusted to their duties and functions. The more number of directors in a sharia banking, the disclosure index of ISR and GRI will increase. 
Imaniyati (2010) states that the task of the sharia supervisory board (DPS) is to oversee the bank's operations and its products to conform to sharia provisions. Zakarsyi (2008) states that the existence of audit committees is expected to provide recommendations of public accountants, assessing matters involving the assignment of public accountants such as engagement letters and estimated fees.

The proposed research hypothesis is as follows:

$\checkmark$ H1a: Sharia bank directors positively influence the disclosure of Islamic Social Reporting Index

$\checkmark$ H1b: Sharia bank directors positively influence the disclosure of Global Reporting Index

$\checkmark$ H2a: Sharia supervisory board has a positive influence on the disclosure of Islamic Social Reporting Index

$\checkmark$ H2b: Sharia supervisory board has a positive influence on the disclosure of the Global Reporting Index

$\checkmark$ H3a: Audit committee positively influences the disclosure of Islamic Social Reporting Index

$\checkmark$ H3b: Audit committee positively influences the disclosure of Global Reporting Index

$\checkmark$ H4: There is a difference (average) between disclosure of annual report with Islamic Social Reporting Index and Global Reporting Initiative Index.

\section{RESEARCH METHODS}

\section{RESEARCH VARIABLES}

Variables in this research consist of: a. DISCLOSURE WITH ISR INDEX

Disclosure with Islamic reporting social index (ISR) is the first dependent variable in this study. Disclosure of this information consists of six aspects including: finance and investment theme, products and service theme, employees theme, society theme, environment, and corporate governance theme. This disclosure is measured using a dummy variable, if the firm discloses the assigned item it will be coded "1", and coded "0" otherwise. Then the total index of ISR disclosure will be calculated using the following formula:

\section{b. DISCLOSURE WITH GRI INDEX}

Disclosure with Global Reporting Initiative Index (GRI) Index is the second dependent variable in this study. This disclosure consists of indicators of economic performance, environmental performance, and social performance consisting of human rights, social, product responsibility, labor and decent work. Disclosure of this sustainability report is based on Global Reporting Initiative Guidelines-3 guidelines. This disclosure is measured using the dummy variable, if the firm discloses the assigned item it will be coded "1", and coded " 0 " otherwise. Then the total index of disclosure of sustainability report will be calculated using the following formula:

c. BOARD OF DIRECTORS

$$
\begin{gathered}
\text { GRI Index }=\frac{\text { Number of GRI Disclosure Items }}{\text { Total Index of GRI Disclosure }} \times 100 \% \\
\text { ISR Index }=\frac{\text { Number of ISR disclosure items }}{\text { Total index of ISR disclosure }} \times 100 \%
\end{gathered}
$$

The Board of Directors is an independent variable in this study which is measured by using the number of directors in a sharia bank.

\section{d. SHARIA SUPERVISORY BOARD}

Sharia supervisory board is an independent variable in this study which is measured by using the number of sharia supervisory boards in an sharia bank.

\section{e. AUDIT COMMITTEE}

Audit Committee is an independent variable in this study which is measured by using the number of audit committees in a Sharia bank. 
This research uses quantitative method by using hypothesis. The data used in this study is secondary data derived from the annual report (annual report) banking. The population of this study is sharia banking in Indonesia which publishes financial statements and annual reports in a row during the period 2013-2016.

\section{Research Model 1}

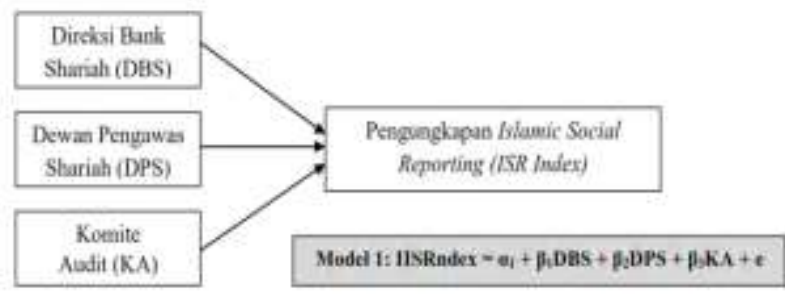

\section{Research Model 2}

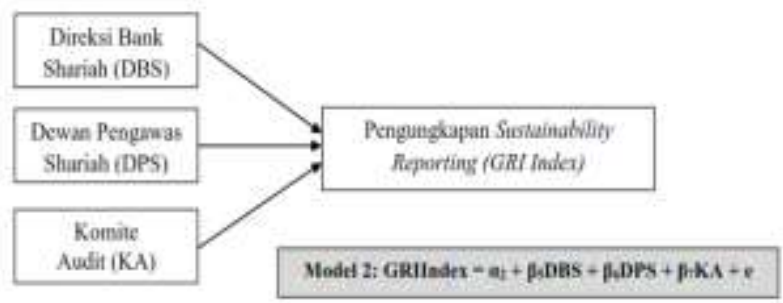

Hypothesis testing $1 \mathrm{a}, 1 \mathrm{~b}, 2 \mathrm{a}, 2 \mathrm{~b}$, $3 \mathrm{a}$ and $3 \mathrm{~b}$ is done by using multiple regression technique using classical assumption test and coefficient of determination test. Test hypothesis 4, using independent test samples t-test to determine whether the average difference between two groups of unrelated samples. Before the test t-test, we will test the similarity of variance (homogeneity) with F- test (Levene's test), if the same variant then t test using equal variance assumed (assumed same variant) and if variant is different using equal variance not assumed (assumed different variant). After that, it will be analyzed the average of higher research data.

\section{RESEARCH RESULT AND DISCUSSION}

Based on the results of data processing, it can be analyzed that:

\section{Tabel 1}

\begin{tabular}{|c|c|c|c|}
\hline \multicolumn{2}{|c|}{ SPSS Test Results } & \multirow[b]{2}{*}{ Sig. } & \multirow[b]{2}{*}{ Result } \\
\hline Model & Variable & & \\
\hline & & *) & \\
\hline & (Constant) & 0 & \\
\hline \multirow{3}{*}{1} & DBS & $\left.0,052^{* *}\right)$ & $\begin{array}{l}\text { Hypothesis } \\
\text { Accepted }\end{array}$ \\
\hline & DPS & 0,407 & $\begin{array}{l}\text { Hypothesis } \\
\text { Rejected }\end{array}$ \\
\hline & KA & 0,642 & $\begin{array}{l}\text { Hypothesis } \\
\text { Rejected }\end{array}$ \\
\hline \multirow[t]{4}{*}{2} & (Constant) & 0,02 & \\
\hline & DBS & 0,842 & $\begin{array}{l}\text { Hypothesis } \\
\text { Rejected }\end{array}$ \\
\hline & DPS & $\left.0,020^{* *}\right)$ & $\begin{array}{l}\text { Hypothesis } \\
\text { Accepted }\end{array}$ \\
\hline & KA & 0,078 & $\begin{array}{l}\text { Hypothesis } \\
\text { Rejected }\end{array}$ \\
\hline
\end{tabular}

*) Level of Significance $=5 \%$ or 0,05

**) Hypothesis

Accepted

Source: SPSS, 2017.

1. Hypothesis $1 \mathrm{a}$ is accepted, because the significance value is 0,000 (sig $\leq$ 0.052). While Hypothesis $1 \mathrm{~b}$ is rejected, because the significance value of 0.842 ( $\mathrm{sig} \geq 0.050$ ). The number of boards of directors has a positive influence on the disclosure of the ISR index, this is because the average board of directors in sharia banks as many as four people, with a sufficient number of directors within a company, the disclosure of the ISR index will increase. the number of boards of directors is less influential on GRI disclosure, this is because the directors have not been able to optimize the disclosure of annual financial statements based on the GRI index that is more global and many indicators (than the ISR index), because sharia banks are more oriented in the disclosure of Islamic principles.

2. Hypothesis $2 \mathrm{a}$ is accepted, because the significance value is 0.020 (sig $\leq$ 0.050 ). While hypothesis $2 \mathrm{~b}$ rejected, 
because the value of significance 0.407 ( $\mathrm{sig} \geq 0.050$ ). The number of sharia supervisory boards has a positive influence on the disclosure of Islamic Reporting Index, while the number of Sharia Supervisory Board in sharia banking has less influence on the disclosure of Global Reporting Index.

The Sharia Supervisory Board (DPS) has the most important role in Sharia aspect control in sharia banking, which is responsible for creating and expressing an opinion from a Sharia Financial Institution for its compliance with sharia so that disclosure is more directed to ISR than GRI.

3. Hypothesis $3 a$ is rejected, because the significance value is 0.642 ( $\mathrm{sig} \geq$ 0.050), whereas Hypothesis $3 \mathrm{~b}$ is rejected, because the significance value is 0.078 ( $\mathrm{sig} \geq 0.050$ ). The number of audit committees has no effect on the disclosure of ISR and GRI indexes. The audit committee has a major role in examining the presentation of fair financial statements. The auditing standards applicable to Sharia banks are audit standards issued and authorized by AAOIFI (Minarni, 2013). However, the concept of financial practice controls performed on Islamic financial institutions in Indonesia has not been fully implemented in accordance with the sharia foundation and is still oriented on the basis of "positive law" which is different and applicable (only) in Indonesia.

4. Hypothesis 4 is accepted, because $P$ value $(0,000<0.05)$, it means there is a difference between the average value of Islamic Social Reporting index with the average value of Global Reporting Index. The average ISR disclosure is $62.65 \%$ higher than the GRI disclosure of only $24.63 \%$. This is because the number of indicators in the ISR disclosure totals 43 items that focus on sharia cores without incorporating conventional aspects. While the disclosure with GRI index amounted to 79 items that are more global and not focused on the aspects of sharia only.

\section{CONCLUSION}

Based on the discussion, this study focuses on the optimization of sharia governance, the board of directors, sharia supervisory board and audit committee in improving the quality of financial reporting disclosure by using ISR and GRI index. Some press points we provide that:

1. The index of Islamic Social Reporting (ISR) has an effect on sharia governance in sharia banking, this is because the indicator used (43 items) focuses on core sharia, which contains indicators that conform to Islamic principles and teachings,

2. The Global Reporting Initiatives (GRI) index is quite influential in sharia governance in sharia banking, this is due to the indicator used (numbering 79 items), consisting of earthly "safety" indicators, in terms of economic, environmental, labor practices and decent work, human rights, community and product responsibility, all of which are of concern to the teachings of Islam but the lack of GRI does not lie in a group (Islam).

3. Comparison of reporting disclosures using ISR and GRI indexes lies in its footing ground, ISR stands for communicating the environmental social effects resulting from economic actions undertaken by a company to a society based on Islamic principles. While GRI is dichotomous (separating science 
and religion) so that the indicator does not inculcate Islamic principles.

Some suggestions and

implications that can be given are:

a) For Sharia Banking, it is expected that the recruitment or development of Human resources (Sharia Human Resources) are familiar with Sharia principles in a kaffah and independent way for the development and functioning of the Sharia Supervisory Board and the Audit Committee.

b) For Bank Indonesia, it is expected that there will be periodic monitoring conducted on sharia banking in accordance with operational procedures that comply with Islamic principles and can maximize the role of supervision of sharia banks in order to compete with conventional banks in accordance with Islamic values, without excluding professionalism as a function of banking in general.

c) The sharia supervisory board is expected to be more independent and focus on the supervision of its sharia aspects and can explicitly undertake its transparent aspects as the sharia supervisory board.

\section{REFERENCE}

Al-Qur'an al-Karim

Al-Hadits

Abeysekera, I. 2011. The relation of intellectual capital disclosure strategies and market value in two political settings. Journal of Intellectual Capital, 12(2), 319338.

doi: 10.1108/14691931111123449

Al-Najjar, B. 2010. Corporate governance and institutional ownership: evidence from Jordan. Corporate Governance, 10(2), 176-
190.

doi:

10.1108/14720701011035693

Anonim. 2006a. Pedoman Laporan Keberlanjutan: Global Reporting Initiative.

Anonim. 2006b. Pedoman Umum Good Corporate Governance Indonesia. Komite Nasional Kebijakan Governance.

Azheri, B. 2011. Corporate Social Responsibility Dari Voluntary Menjadi Mandatory. Jakarta: PT Rajagrafindo Persada.

Bhagwat, P. 2011. Corporate Social Responsibility and Sustanaible Development. [Conference on Inclusive \& Sustainable Growth].

Branswijck, D., Patricia Everaert. 2013. Intellectual capital disclosure commitment: myth or reality? Journal of Intellectual Capital, 13(2013), 35-96. doi: DOI 10.1108/14691931211196204

Brüggen, A., Vergauwen, P., \& Dao, M. 2009. Determinants of intellectual capital disclosure: evidence from Australia. Management Decision, 47(2), 233-245. doi: 10.1108/00251740910938894

Bukh, P. N., Nielsen, C., Gormsen, P., \& Mouritsen, J. 2005. Disclosure of information on intellectual capital in Danish IPO prospectuses. Accounting, Auditing \& Accountability Journal, 18(6), 713732.

Burhan, A. H. N., \& Rahmanti, W. 2013. Dampak Kesinambungan Pelaporan Pada Kinerja Perusahaan Journal of Economics, Business, and Accountancy Ventura, 15, 257-272.

Chariri, A., \& Nugroho, F. A. 2009. Retorika Dalam Pelaporan Corporate Social Responsibility: Analisis Semiotik Atas Sustainability Reporting PT. Aneka Tambang Tbk. Simposium Nasional Akuntansi XII Palembang. 
Daizy, \& Das, N. 2014. Sustainability Reporting Framework: Comparative Analysis of Global Reporting Initiatives and Dow Jones Sustainability Index. International Journal of Science, Environment and Technology, Vol 3 No 1, 55-66.

Darus, F., Arshad, R., \& Othman, S. 2009. Influence of Institutional Pressure and Ownership Structure on Corporate Social Responsibility Disclosure. Interdisciplinary Journal of Contemporary Research in Business, Vol 1 No. 5.

Darussalam, Andi Zulfikar. Konsep Perdagangan dalam Tafsir AlMishbah (Paradigma Filsafat Ekonomi Qur'ani Ulama Indonesia). Jurnal Al-Tijarah UNIDA Gontor, Vol. 3, No. 1, 45-64.

Dye, R. A. 2001. An evaluation of "essays on disclosure" and the disclosure literature in accounting. Journal of accounting and economics, 32(1), 181-235.

Ghazali, N. A. M. 2007. Ownership structure and corporate social responsibility disclosure: some Malaysian evidence. Corporate Governance, 7 (3), 251-266. doi: 10.1108/ 14720700710756535

Ghozali, I. 2011. Aplikasi Analisis Multivariate dengan Program IBM SPSS 19. Semarang: Badan Penerbit Universitas Diponegoro.

Ghozali, I. 2013. Aplikasi Analisis Multivariate dengan Program IBM SPSS 21 Update PLS Regresi. Semarang: Badan Penerbit Universitas Diponegoro.

Hadiprajitno, P. B. 2013. Struktur Kepemilikan, Mekanisme Tata Kelola Perusahaan, dan Biaya Keagenan di Indonesia. Jurnal Akuntansi \& Auditing, 9(2), 97127.

Idah. 2013. Corporate Governance dan Karakteristik Perusahaan Dalam
Pengungkapan Sustainability Report. Accounting Analysis Journal, Vol 2, 314-322.

Jensen, M. C., \& Meckling, W. H. 1976. Theory of the firm: Managerial behavior, agency costs and ownership structure. Journal of financial economics, 3(4), 305-360

Jihene, F., \& Robert, P. 2013. The effect of intellectual capital disclosure on the value creation: An empirical study using Tunisian annual reports. International Journal of Accounting and Financial Reporting, Vol. 3 NO. 1.

Ogundare, E. A. 2013. The Impact of Sustainability Reporting on Organizational Performance - The Malaysia Experience. International Journal of Accounting, and Business Management (IJABM), Volume 1(Issue 1).

Riswandi, B. A. 2006. Permasalahan Implementasi Prinsip-Prinsip Good Corporate Governance Pada BUMN di Indonesia. Jurnal Fenomena, Vol. 4 No. 2.

Rustiarini, N. W. 2010. Pengaruh Corporate Governance Pada Hubungan Corporate Social Responsibility dan Nilai Perusahaan. Simposium Nasional Akuntansi 13 Purwokerto.

Sari, M. P. Y., \& Marsono. 2013. Pengaruh Kinerja keuangan, Ukuran Perusahaan dan Corporate Governance Terhadap Pengungkapan Sustainability Report. Volume 2 Nomor 3.

Sawono, J. 2013. Model-model Linier dan Non-Linier Dalam IBM SPSS 21 Prosedur-prosedur Alternatif Untuk Riset Skripsi.

Zakarsyi, d. H. M. W. 2008. Good Corporate Governance Pada Badan Usaha Manufaktur, Perbankan, dan Jasa Keuangan Lainnya. Bandung: Alfabeta. 